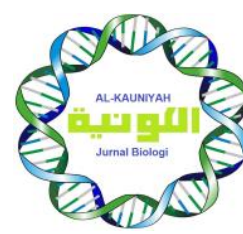

Available online at AL-KAUNIYAH: Jurnal Biologi

Website: http://journal.uinjkt.ac.id/index.php/kauniyah

AL-KAUNIYAH: Jurnal Biologi, 14(1), 2021, 29-41

\title{
STRUKTUR ANATOMI DAUN PHYLLANTHACEAE DI KABUPATEN BANGGAI KEPULAUAN
}

\section{ANATOMICAL STRUCTURE OF PHYLLANTHACEAE LEAF FROM BANGGAI KEPULAUAN}

\author{
Tri Yuni Indah Wulansari*, Asih Perwita Dewi \\ Lembaga Ilmu Pengetahuan Indonesia, Jl. Raya Jakarta-Bogor km 46, Cibinong - Bogor 16911 \\ *Corresponding author: triyuniindahwulansari@yahoo.co.id
}

Naskah Diterima: 27 Januari 2020; Direvisi: 9 Juli 2020; Disetujui: 10 November 2020

\begin{abstract}
Abstrak
Pengenalan ciri makhluk hidup dalam praktik identifikasi sebagian besar menggunakan ciri morfologi. Ciri anatomi memperkuat ciri morfologi atau menyelesaikan permasalahan kerancuan identifikasi secara morfologi. Penelitian ini bertujuan untuk mengetahui karakter anatomi daun pada 11 spesies famili Phyllanthaceae yang ditemukan di wilayah eksplorasi Kabupaten Banggai Kepulauan. Metode yang digunakan adalah pembuatan preparat paradermal dan transversal helai dan tangkai daun. Karakter yang diamati pada setiap preparat adalah karakter paradermal yaitu epidermis dan derivatnya, karakter transversal meliputi bentuk dan jumlah lapisan epidermis, mesofil, keberadaan kristal dan karakter khusus spesies serta bentuk berkas pengangkut pada tulang daun dan tangkai daun. Berdasarkan preparat paradermal daun diperoleh tipe daun hipostomatik dengan tipe stomata umumnya parasitik dan anomositik, dan ditemukan variasi tipe stomata anisositik pada Baccaurea nanihua dan Antidesma excavatum. Pada preparat transversal diperoleh tipe daun dorsiventral, bentuk epidermis dan jaringan tiang yang beragam. Pada organ tangkai daun, ditemukan empat tipe berkas pengangkut, yaitu bentuk lonjong dengan dua tambahan berkas pengangkut, bentuk dasar menyerupai ginjal, bentuk semi-lunar, dan bentuk lonjong dengan satu berkas pengangkut.
\end{abstract}

Kata kunci: Helai daun; Karakter anatomi; Phyllanthaceae; Tangkai daun

\begin{abstract}
Morphological characters are commonly used as a tool for plant identification. Anatomical characters can also be used as additional characters to provide strong descriptions of morphological characters and to resolve unclear identification of morphological characters. This study aims to identify leaf anatomical characters of 11 species of Phyllanthaceae family collected from the Banggai Kepulauan Regency. The characters are observed in each slide were paradermal characters, namely epidermis and its derivatives; transverse characters including the shape and number of epidermal layers, mesophyll, presence of crystals and species-specific characters as well as the shape of the vascular bundle on the midrib and petiole. The observation on paradermal section of lamina showed that all species have hypostomatic leaf, parasitic and anomocytic stomata types with variation of the anisocytic types were found in Baccaurea nanihua and Antidesma excavatum.Observation of the transverse section showed dorsiventral leaf types, size variation of upper epidermal cells as well as variations of palisade cells. The observation on transverse section of the petiole showed four types of vascular bundles in the petiole: oval shape along with two small separated vascular, the kidney - like shape, the semi-lunar shape and oval single vascular bundle.
\end{abstract}

Keywords: Anatomycal characters; Lamina; Petiole; Phyllanthaceae

Permalink/DOI: http://dx.doi.org/10.14395/kauniyah.v14i1.14395 


\section{PENDAHULUAN}

Kabupaten

Banggai

Kepulauan merupakan salah satu wilayah administratif yang menjadi bagian dari Provinsi Sulawesi Tengah. Secara geografis, Provinsi Sulawesi Tengah memiliki beberapa gugus kepulauan di luar daratan utama. Hal ini menjadi suatu khasanah penelitian terutama dalam kaitannya dengan teori MacArthur dan Wilson tentang biogeografi pulau (Wu \& Vankat, 1995) yang secara jangka panjang dapat menimbulkan endemisitas flora dan fauna.

Penelitian yang dilaksanakan pada dua pulau, yaitu Pulau Peleng dan Pulau Bakalan memiliki fokus eksplorasi di wilayah terestrial dan wilayah bakau. Wilayah terestrial Pulau Peleng dan Bangkalan memiliki kontur perbukitan, dengan tipe vegetasi yang menyusunnya adalah vegetasi hutan sekunder. Investigasi persebaran vegetasi pada wilayah terestrial dilakukan berdasarkan keanekaragaman vegetasi flora yang ditemui secara umum. Informasi komposisi vegetasi di suatu wilayah berguna untuk menjadi data acuan apabila di masa yang akan datang terjadi perubahan komposisi hutan akibat adanya gangguan yang bersifat alami maupun akibat campur tangan manusia (Whitmore, 1991).

Famili yang menjadi fokus dalam penelitian ini, yaitu famili Phyllanthaceae yang merupakan salah satu famili dengan keanekaragaman spesies yang melimpah ditemukan di wilayah eksplorasi. Pengenalan keanekaragaman spesies selain dilakukan dengan pengamatan morfologi, dapat pula dilakukan dengan pengamatan mikroskopis melalui karakter anatomi. Ekspresi morfologi yang tampak merupakan bentuk dari interaksi sel yang beradaptasi terhadap faktor lingkungan yang diserap oleh tumbuhan seperti asupan hara, air, dan kondisi abiotik seperti cekaman kekeringan maupun kelembapan. Interaksi sel tersebut kemudian secara permanen memberikan identitas spesifik yang dapat teramati untuk mendukung karakter morfologi dan memisahkan tumbuhan dalam tingkatan taksa spesies, genus, maupun famili.

Identifikasi secara morfologi paling umum digunakan, namun pada banyak kasus pengamatan anatomi dapat digunakan untuk membantu pengelompokan atau memperkuat ciri khusus suatu individu pada suatu tingkatan taksa. Penelitian Aziagba, Okwuchukwu, Ke, dan Uwabukeonye (2017) merupakan salah satu contoh penggunaan karakter anatomi untuk memperkuat perbedaan varietas pada Vigna unguiculata, yaitu dengan diketahuinya perbedaan susunan berkas pengangkut pada batang dan tangkai daun dari tiga varietas yang diamati. Selain itu, Cahyanto, Sopian, Efendi, dan Kinasih (2017) juga membedakan kultivar mangga Subang salah satunya dengan bentuk jaringan pengangkut dan bentuk kristal oksalat pada penampang melintang tangkai daun. Karakter anatomi yang difokuskan pada penelitian ini adalah anatomi daun. Karakter anatomi daun seperti tipe stomata dan epidermis telah banyak disertakan sebagai objek pengamatan morfologi, anatomi, dan fisiologi (Van Cotthem, 1970). Penelitian ini bertujuan untuk mengetahui karakter anatomi daun pada 11 spesies famili Phyllanthaceae yang ditemukan di wilayah eksplorasi Kabupaten Banggai Kepulauan.

\section{MATERIAL DAN METODE}

Sampel helaian dan tangkai daun didapatkan dari kegiatan eksplorasi di Kabupaten Banggai Kepulauan, Sulawesi Tengah. Terdapat 11 spesies anggota famili Phyllanthaceae, yaitu Antidesma sp., Antidesma celebicum Miq., Antidesma excavatum Miq., Baccaurea nanihua Merr., Breynia cernua (Poir.) Mull. Arg., Breynia macrantha (Hassk.) Chakrab. \& N. P. Balakr., Breynia vestita Warb., Glochidion sp., Glochidion philippicum (Cav.) C. B. Rob, Glochidion zeylanicum (Gaertn.) A. Juss. dan Phyllanthus mollis (Blume) Mull. Arg.

Sampel daun dan tangkai daun dibuat preparat secara transversal menggunakan metode Sass (1951). Daun dan tangkai daun dipotong kurang lebih $1 \mathrm{~cm}$ kemudian dimasukkan dalam larutan fiksatif formalin : asam asetat glasial : alkohol (FAA) selama 24 jam. Tahapan selanjutnya adalah dehidrasi dengan alkohol bertingkat dan dilanjutkan dengan dealkoholisasi menggunakan campuran alkohol : xilol bertingkat sampai dengan xilol murni. Sampel daun dan tulang daun kemudian diinfiltrasi dan dilakukan penyelubungan menggunakan parafin. Pengirisan jaringan menggunakan mikrotom dengan tebal $\pm 15 \mu \mathrm{m}$. Pewarnaan preparat menggunakan dua jenis 
pewarna, yaitu safranin dan fast green. Preparat paradermal daun dibuat dengan metode Cutler (1978) menggunakan asam kuat $\mathrm{HNO}_{3}$ (1:3) untuk memisahkan bagian epidermis daun dari mesofil. Bagian epidermis yang telah terpisah kemudian diberi pewarna safranin untuk mempermudah pengamatan. Preparat paradermal digunakan untuk pengamatan tipe stomata dan derivat epidermis lain serta pengamatan bentuk epidermis dan tipe dinding antiklinalnya.

Pengamatan preparat menggunakan mikroskop Nikon Eclipse 80i yang terhubung dengan kamera XCAM 1080 PHB 2,4 x 2,4 pixel untuk dokumentasi dengan aplikasi Beta View. Penghitungan indeks stomata mengikuti Wilmer (1983) dengan rumus indeks stomata: [jumlah stomata/(jumlah stomata + jumlah epidermis)] X 100. Data yang didapat kemudian dibandingkan dan dideskripsikan untuk mengetahui karakter anatomi dari masing-masing spesies.

\section{HASIL}

Dari hasil sayatan paradermal helai daun 11 spesies famili Phyllanthaceae diketahui hanya memiliki stomata di bagian bawah daun (hipostomatik). Tipe stomata pada umumnya parasitik (Gambar 1a) dan anomositik (Gambar 1c), tetapi ditemukan pula stomata anisositik pada Baccaurea nanihua dan sedikit pada Antidesma excavatum (Gambar 1b). Pada sayatan paradermal juga terlihat perbedaan dinding antiklinal serta bentuk epidermis dari tiap spesies baik epidermis atas maupun epidermis bawah. Dinding antiklinal epidermis pada pengamatan ini dikelompokkan menjadi lurus, melengkung, bergelombang, melekuk, dan melekuk dalam. Dinding antiklinal epidermis bawah sebagian besar memiliki tipe bergelombang (Gambar 1a) sampai melekuk (Gambar 1c) kecuali pada Breynia vestita yang memiliki dinding antiklinal lurus. Dinding antiklinal epidermis atas memiliki tipe lurus sampai melekuk. Bentuk sel epidermis pada penelitian ini hanya terdiri dari 2 tipe, yaitu poligonal (dengan 4-8 sisi) dan tidak beraturan bagi sel yang memiliki lekukan pada dinding antiklinal. Trikoma sebagian besar ditemukan pada daerah epidermis bawah dengan bentuk umumnya tunggal uniseluler (Gambar 1d) kecuali pada $B$. nanihua yang dicirikan dengan trikoma bentuk bintang (Gambar 1e). Karakter anatomi paradermal yang diamati secara keseluruhan dapat dilihat pada Tabel 1 .

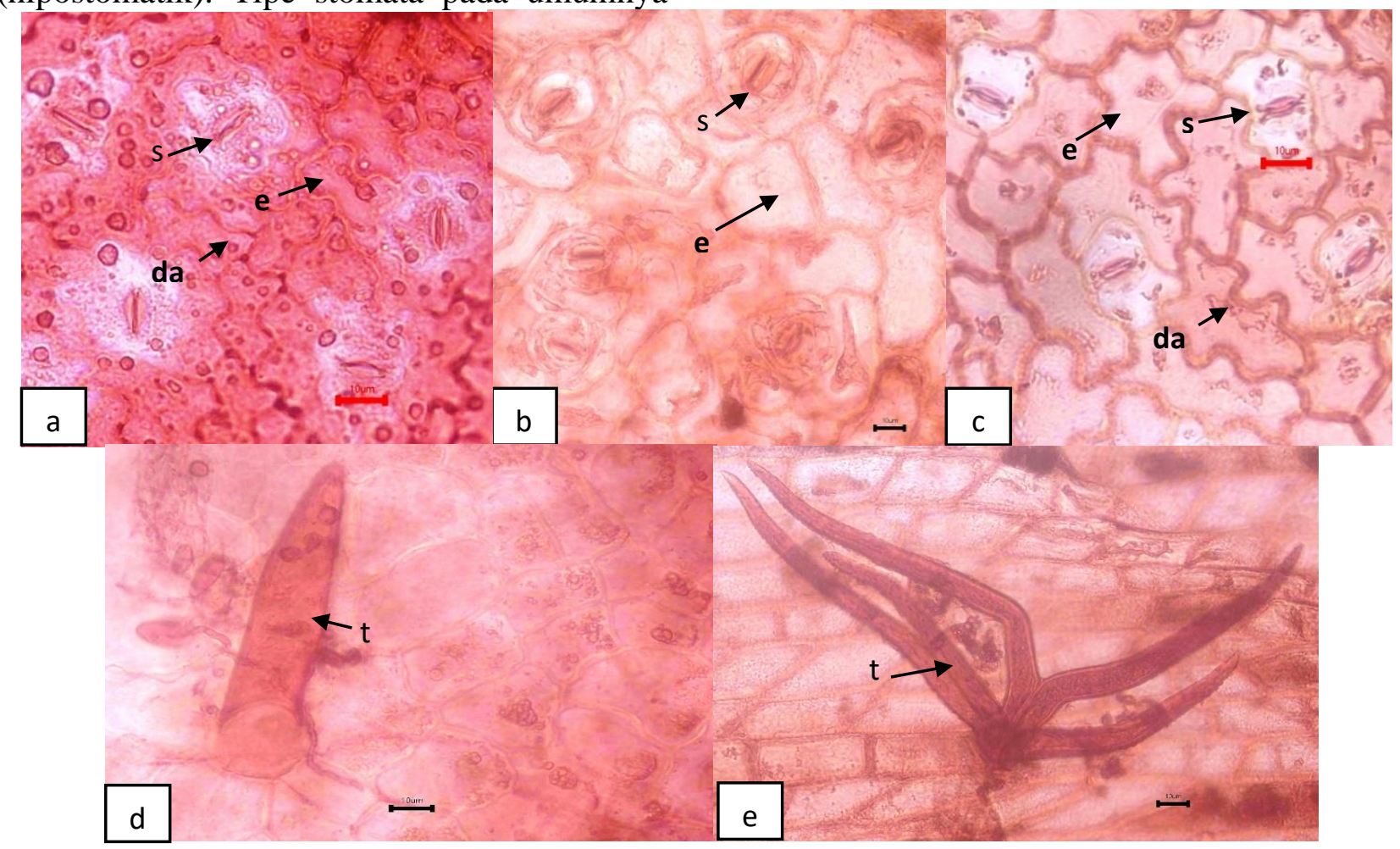

Gambar 1. Tipe stomata dan trikoma pada 11 spesies famili Phyllanthaceae. Stomata parasitik (a), stomata anisositik (b), stomata anomositik (c), trikoma tunggal uniseluler (d), dan trikoma bentuk rambut bintang (e). Keterangan gambar, yaitu e= epidermis, $\mathrm{da}=$ dinding antiklinal, $\mathrm{s}=$ stomata, $\mathrm{t}=$ trikoma. Scale bar $=10 \mu \mathrm{m}$ 
Selain tipe stomata, juga diamati karakter lain seperti panjang stomata, lebar stomata, dan indeks stomata (Gambar 2). Spesies-spesies dari genus Glochidion dan Breynia memiliki

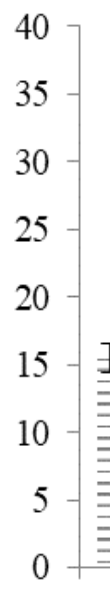

A sp.
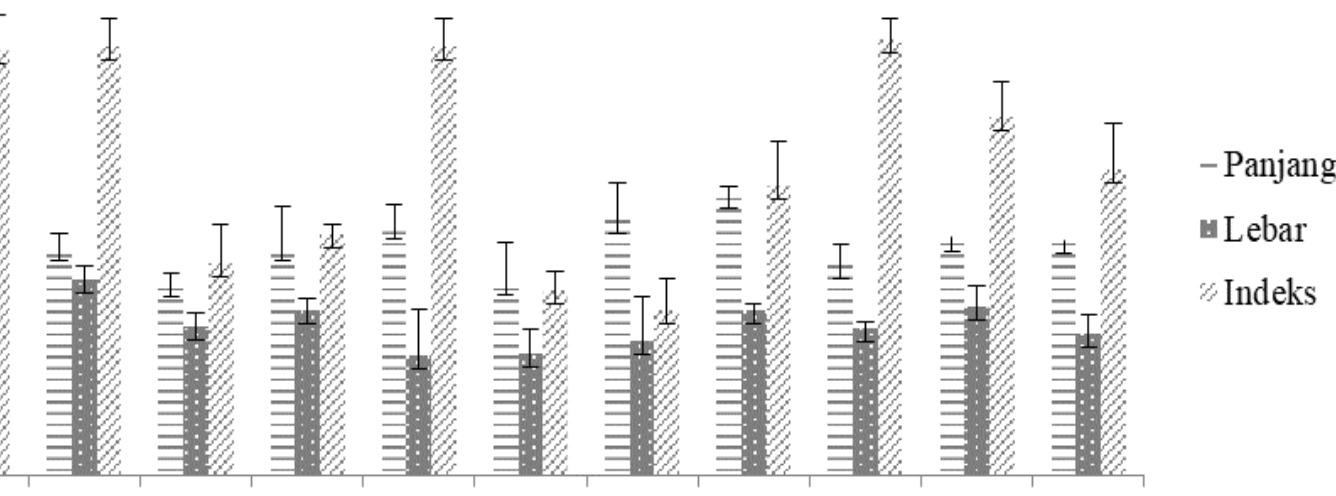

Gambar 2. Ukuran panjang stomata dan lebar stomata $(\mu \mathrm{m})$ serta indeks stomata $(\%)$ tiap spesies. Keterangan urutan spesies: A sp. (Antidesma sp.), A.c (Antidesma celebicum), A.e (Antidesma excavatum), B.n (Baccaurea nanihua), Br.c (Breynia cernua), Br. m (Breynia macrantha), Br.v (Breynia vestita), G sp. (Glochidion sp.), G.p (Glochidion philippicum), G.z (Glochidion zeylanicum) dan P.m (Phyllathus mollis)

Pengamatan selanjutnya dari sampel dilakukan secara transversal atau bagian melintang dari daun maupun tangkai daun. Karakter anatomi daun secara transversal seluruh spesies dapat dilihat pada Tabel 2 . Berdasarkan susunannya, seluruh spesies memiliki tipe yang sama, yaitu daun dorsiventral dengan parenkim jaringan tiang terletak pada bagian atas dan parenkim jaringan bunga karang pada bagian bawah. Epidermis atas dan bawah masing-masing terdiri dari satu lapis sel dengan sel yang seragam kecuali pada genus Antidesma, yaitu epidermis atasnya tersusun dari sel-sel yang memiliki ukuran beragam (Gambar 3a), sedangkan pada epidermis bawah yang memiliki penampakan berbeda adalah $B$. cernua karena berpapila. Jaringan tiang umumnya terdiri dari 1 lapis kecuali pada Antidesma yang terdiri dari 2-4 lapis jaringan tiang. Perbedaan lain adalah bentuk jaringan tiang yang beraneka macam, yaitu pendek dan persegi (Gambar 3a), memanjang (Gambar 3b), serta meruncing (Gambar 3c). Jaringan bunga karang dikelompokkan berdasarkan kerapatannya dan ruang antar selnya. Seluruh sampel yang diamati memiliki kristal kalsium oksalat bentuk druse, keberadaan kristal kalsium oksalat tersebar mulai dari epidermis, mesofil sampai dengan parenkim berkas pengangkut.

Bagian lain yang diamati adalah struktur anatomi berkas pengangkut pada tangkai daun. Pada pengamatan ini, karakter yang difokuskan adalah bentuk berkas pengangkut. Susunan berkas pengangkut memiliki formasi yang sama, yaitu floem di bagian luar dan xilem di dalam. Hasil pengamatan terhadap sampel didapatkan empat tipe utama berkas pengangkut tangkai daun yaitu bentuk lonjong dengan tambahan dua berkas pengangkut (Gambar 4a), bentuk lonjong dengan satu berkas pengangkut (Gambar 4b), bentuk semi lunar (Gambar 4c), dan bentuk menyerupai ginjal dengan variasinya (Gambar 4d). Hasil pengamatan menunjukkan bahwa spesiesspesies dari genus Antidesma pada penelitian ini memiliki bentuk berkas pengangkut tangkai daun yang sama, yaitu tiga berkas pengangkut (Gambar 4a). Spesies-spesies dari genus Breynia memiliki bentuk berkas dengan rentang semi lunar sampai menyerupai ginjal (Gambar 4c-d1) sedangkan pada Glochidion meskipun cukup bervariasi pada dasarnya berbentuk menyerupai ginjal (Gambar 4d2-d4). 


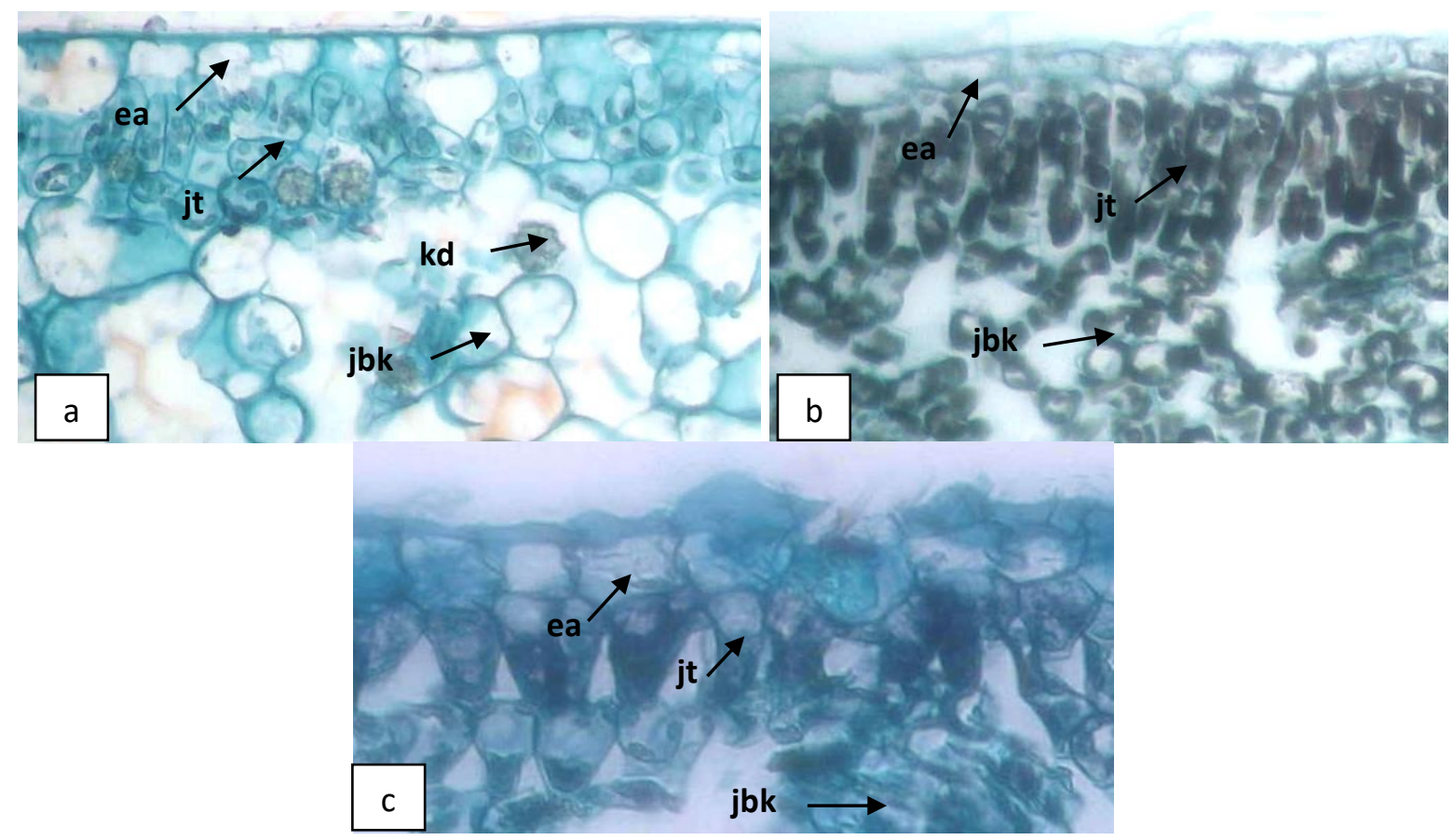

Gambar 3. Perbedaan bentuk dan ukuran epidermis atas dan jaringan tiang daun Phyllanthaceae. Epidermis atas dengan ukuran tidak seragam dan jaringan tiang silinder pendek dan persegi (Antidesma sp.) (a), epidermis atas seragam dan jaringan tiang memanjang (Breynia vestita) (b), serta epidermis seragam dan jaringan tiang meruncing (Baccaurea nanihua) (c). Keterangan: ea= epidermis atas, jbk= jaringan bunga karang, $\mathrm{jt}=$ jaringan tiang, $\mathrm{kd}=\mathrm{kristal}$ druse

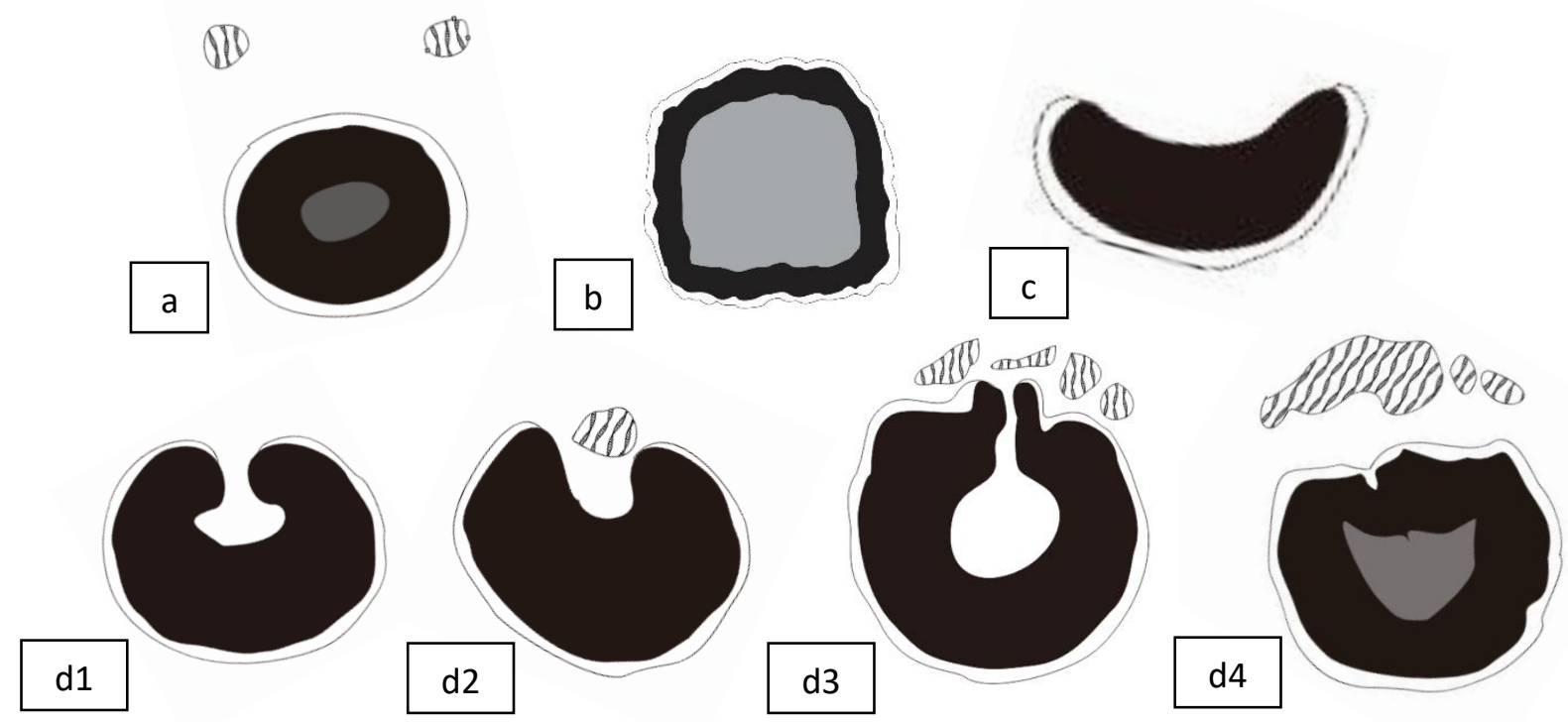

Gambar 4. Bentuk berkas pengangkut tangkai daun pada Phyllanthaceae, yaitu bentuk lonjong dengan tiga berkas pengangkut pada genus Antidesma (a), bentuk lonjong dengan satu berkas pengangkut pada Baccaurea nanihua (b), bentuk semi-lunar pada Phyllanthus mollis, Breynia cernua dan Breynia vestita (c), bentuk menyerupai ginjal pada Breynia macrantha (d), bentuk menyerupai ginjal dengan tambahan berkas pengangkut pada genus Glochidion beserta variasinya pada Glochidion sp. (d2), Glochidion zeylanicum (d3) dan Glochidion philippicum (d4). Keterangan warna: hitam= xilem, putih= floem, kelabu= empulur, dan bercorak= berkas pengangkut tambahan 
AL-KAUNIYAH: Jurnal Biologi, 14(1), 2021

Tabel 1. Karakter Anatomi Bagian Paradermal Daun Dari 11 Spesies Phyllanthaceae di Kabupaten Banggai Kepulauan

\begin{tabular}{|c|c|c|c|c|c|c|c|}
\hline \multirow[t]{2}{*}{ Nama spesies } & \multicolumn{3}{|c|}{ Epidermis bawah } & \multicolumn{2}{|c|}{ Epidermis atas } & \multirow{2}{*}{$\begin{array}{c}\text { Bentuk } \\
\text { trikoma }\end{array}$} & \multirow{2}{*}{$\begin{array}{c}\text { Keberadaan } \\
\text { trikoma }\end{array}$} \\
\hline & Stomata & $\begin{array}{c}\text { Dinding } \\
\text { antiklinal }\end{array}$ & Bentuk sel & $\begin{array}{c}\text { Dinding } \\
\text { antiklinal }\end{array}$ & Bentuk sel & & \\
\hline Antidesma sp. & Parasitik & Melekuk & $\begin{array}{l}\text { Tidak } \\
\text { beraturan }\end{array}$ & $\begin{array}{l}\text { Bergelombang- } \\
\text { melekuk }\end{array}$ & $\begin{array}{l}\text { Tidak } \\
\text { beraturan }\end{array}$ & - & - \\
\hline $\begin{array}{l}\text { Antidesma } \\
\text { celebicum }\end{array}$ & Parasitik & Bergelombang & $\begin{array}{l}\text { Tidak } \\
\text { beraturan }\end{array}$ & $\begin{array}{l}\text { Bergelombang- } \\
\text { melekuk }\end{array}$ & $\begin{array}{l}\text { Tidak } \\
\text { beraturan }\end{array}$ & - & - \\
\hline $\begin{array}{l}\text { Antidesma } \\
\text { excavatum }\end{array}$ & $\begin{array}{l}\text { Parasitik (dominan), } \\
\text { anomositik dan } \\
\text { anisositik }\end{array}$ & $\begin{array}{l}\text { Bergelombang- } \\
\text { melekuk }\end{array}$ & $\begin{array}{l}\text { Tidak } \\
\text { beraturan }\end{array}$ & $\begin{array}{l}\text { Bergelombang- } \\
\text { melekuk }\end{array}$ & $\begin{array}{l}\text { Tidak } \\
\text { beraturan }\end{array}$ & - & - \\
\hline $\begin{array}{l}\text { Baccaurea } \\
\text { nanihua }\end{array}$ & Anisositik & $\begin{array}{l}\text { Melengkung - } \\
\text { bergelombang }\end{array}$ & $\begin{array}{l}\text { Tidak } \\
\text { beraturan }\end{array}$ & $\begin{array}{l}\text { Lurus- } \\
\text { bergelombang }\end{array}$ & $\begin{array}{l}\text { Poligonal- } \\
\text { tidak } \\
\text { beraturan }\end{array}$ & $\begin{array}{l}\text { Bercabang } \\
\text { non glanduler } \\
\text { (stellate) }\end{array}$ & $\begin{array}{l}\text { Epidermis } \\
\text { bawah }\end{array}$ \\
\hline Breynia cernua & $\begin{array}{l}\text { Parasitik, } \\
\text { anomositik }\end{array}$ & Bergelombang & $\begin{array}{l}\text { Tidak } \\
\text { beraturan }\end{array}$ & Lurus & Poligonal & $\begin{array}{l}\text { Tunggal } \\
\text { uniseluer }\end{array}$ & $\begin{array}{l}\text { Epidermis } \\
\text { bawah }\end{array}$ \\
\hline Breynia macrantha & $\begin{array}{l}\text { Parasitik, } \\
\text { anomositik }\end{array}$ & Melekuk & $\begin{array}{l}\text { Tidak } \\
\text { beraturan }\end{array}$ & Lurus & Poligonal & - & - \\
\hline Breynia vestita & $\begin{array}{l}\text { Parasitik, } \\
\text { anomositik }\end{array}$ & $\begin{array}{l}\text { Lurus - } \\
\text { bergelombang }\end{array}$ & $\begin{array}{l}\text { Poligonal - } \\
\text { Tidak } \\
\text { beraturan }\end{array}$ & Lurus & Poligonal & $\begin{array}{l}\text { Tunggal } \\
\text { multiseluler } \\
\text { non glanduler }\end{array}$ & $\begin{array}{l}\text { Epidermis } \\
\text { bawah }\end{array}$ \\
\hline Glochidion sp. & Parasitik & $\begin{array}{l}\text { Melekuk- } \\
\text { melekuk dalam }\end{array}$ & $\begin{array}{l}\text { Tidak } \\
\text { beraturan }\end{array}$ & $\begin{array}{l}\text { Bergelombang- } \\
\text { melekuk }\end{array}$ & $\begin{array}{l}\text { Tidak } \\
\text { beraturan }\end{array}$ & - & - \\
\hline $\begin{array}{l}\text { Glochidion } \\
\text { philippicum }\end{array}$ & $\begin{array}{l}\text { Parasitik, } \\
\text { anomositik }\end{array}$ & $\begin{array}{l}\text { Melengkung- } \\
\text { bergelombang }\end{array}$ & $\begin{array}{l}\text { Tidak } \\
\text { beraturan }\end{array}$ & Lurus & Poligonal & $\begin{array}{l}\text { Tunggal } \\
\text { uniseluler }\end{array}$ & $\begin{array}{l}\text { Epidermis } \\
\text { bawah }\end{array}$ \\
\hline $\begin{array}{l}\text { Glochidion } \\
\text { zeylanicum }\end{array}$ & Parasitik & Bergelombang & $\begin{array}{l}\text { Tidak } \\
\text { beraturan }\end{array}$ & $\begin{array}{l}\text { Lurus- } \\
\text { bergelombang }\end{array}$ & $\begin{array}{l}\text { Poligonal- } \\
\text { tidak } \\
\text { beraturan }\end{array}$ & - & - \\
\hline Phyllanthus mollis & $\begin{array}{l}\text { Parasitik, } \\
\text { anomositik }\end{array}$ & Melekuk & $\begin{array}{l}\text { Tidak } \\
\text { beraturan }\end{array}$ & $\begin{array}{l}\text { Lurus- } \\
\text { bergelombang }\end{array}$ & $\begin{array}{l}\text { Poligonal- } \\
\text { tidak } \\
\text { beraturan }\end{array}$ & $\begin{array}{l}\text { Tunggal } \\
\text { multiseluler } \\
\text { non glanduler }\end{array}$ & $\begin{array}{l}\text { Epidermis } \\
\text { atas dan } \\
\text { bawah }\end{array}$ \\
\hline
\end{tabular}


AL-KAUNIYAH: Jurnal Biologi, 14(1), 2021

Tabel 2. Karakter Anatomi Bagian Transversal Daun Dari 11 spesies Phyllanthaceae di Kabupaten Banggai Kepulauan

\begin{tabular}{|c|c|c|c|c|c|c|c|}
\hline \multirow[b]{2}{*}{ Nama spesies } & \multicolumn{3}{|c|}{ Jumlah lapisan dan bentuk } & \multirow{2}{*}{$\begin{array}{l}\text { Kerapatan } \\
\text { jaringan } \\
\text { bunga } \\
\text { karang } \\
\end{array}$} & \multirow{2}{*}{$\begin{array}{l}\text { Bentuk } \\
\text { kalsium } \\
\text { oksalat }\end{array}$} & \multirow{2}{*}{$\begin{array}{c}\text { Keberadaan kalsium } \\
\text { oksalat }\end{array}$} & \multirow[b]{2}{*}{$\begin{array}{c}\text { Kenampakan } \\
\text { khusus }\end{array}$} \\
\hline & Epidermis atas & $\begin{array}{l}\text { Epidermis } \\
\text { bawah }\end{array}$ & Jaringan tiang & & & & \\
\hline Antidesma sp. & $\begin{array}{l}1 \text { lapis, sel } \\
\text { tidak seragam }\end{array}$ & $\begin{array}{l}1 \text { lapis, sel } \\
\text { seragam }\end{array}$ & $\begin{array}{l}2 \text { lapis, silinder } \\
\text { pendek dan } \\
\text { persegi }\end{array}$ & Cukup rapat & Druse & $\begin{array}{l}\text { Jaringan bunga karang, } \\
\text { jaringan tiang, dan } \\
\text { parenkim berkas } \\
\text { pengangkut }\end{array}$ & - \\
\hline $\begin{array}{l}\text { Antidesma } \\
\text { celebicum }\end{array}$ & $\begin{array}{l}1 \text { lapis, sel } \\
\text { tidak seragam }\end{array}$ & $\begin{array}{l}1 \text { lapis, sel } \\
\text { seragam }\end{array}$ & $\begin{array}{l}\text { 2-3 lapis, } \\
\text { memanjang dan } \\
\text { persegi }\end{array}$ & Tidak rapat & Druse & $\begin{array}{l}\text { Parenkim berkas } \\
\text { pengangkut }\end{array}$ & - \\
\hline $\begin{array}{l}\text { Antidesma } \\
\text { excavatum }\end{array}$ & $\begin{array}{l}1 \text { lapis, sel } \\
\text { tidak seragam }\end{array}$ & $\begin{array}{l}1 \text { lapis, sel } \\
\text { seragam }\end{array}$ & $\begin{array}{l}\text { 3-4 lapis, } \\
\text { silinder pendek } \\
\text { dan persegi }\end{array}$ & Cukup rapat & Druse & Jaringan tiang & - \\
\hline $\begin{array}{l}\text { Baccaurea } \\
\text { nanihua }\end{array}$ & $\begin{array}{l}1 \text { lapis, sel } \\
\text { seragam }\end{array}$ & $\begin{array}{l}1 \text { lapis, sel } \\
\text { seragam }\end{array}$ & $\begin{array}{l}\text { 1-2 lapis, } \\
\text { meruncing }\end{array}$ & Tidak rapat & Druse & $\begin{array}{l}\text { Epidermis atas, } \\
\text { jaringan bunga karang, } \\
\text { jaringan tiang, dan } \\
\text { parenkim berkas } \\
\text { pengangkut }\end{array}$ & - \\
\hline Breynia cеrnua & $\begin{array}{l}1 \text { lapis, sel } \\
\text { seragam }\end{array}$ & $\begin{array}{l}1 \text { lapis, sel } \\
\text { epid bawah } \\
\text { berpapila }\end{array}$ & $\begin{array}{l}1 \text { lapis, } \\
\text { memanjang }\end{array}$ & Tidak rapat & Druse & $\begin{array}{l}\text { Parenkim berkas } \\
\text { pengangkut }\end{array}$ & $\begin{array}{l}\text { Hipodermis } \\
\text { pada daerah } \\
\text { dekat berkas } \\
\text { pengangkut } \\
\text { tulang daun }\end{array}$ \\
\hline $\begin{array}{l}\text { Breynia } \\
\text { macrantha }\end{array}$ & $\begin{array}{l}1 \text { lapis, sel } \\
\text { seragam }\end{array}$ & $\begin{array}{l}1 \text { lapis, sel } \\
\text { seragam }\end{array}$ & $\begin{array}{l}1 \text { lapis, silinder } \\
\text { pendek }\end{array}$ & Tidak rapat & Druse & $\begin{array}{l}\text { Jaringan bunga karang } \\
\text { dan parenkim berkas } \\
\text { pengangkut }\end{array}$ & - \\
\hline Breynia vestita & $\begin{array}{l}1 \text { lapis, sel } \\
\text { seragam }\end{array}$ & $\begin{array}{l}1 \text { lapis, sel } \\
\text { seragam }\end{array}$ & $\begin{array}{l}1 \text { lapis, } \\
\text { memanjang }\end{array}$ & Tidak rapat & Druse & Jaringan bunga karang & - \\
\hline Glochidion sp. & $\begin{array}{l}1 \text { lapis, sel } \\
\text { seragam }\end{array}$ & $\begin{array}{l}1 \text { lapis, sel } \\
\text { seragam }\end{array}$ & $\begin{array}{l}1 \text { lapis, } \\
\text { memanjang } \\
\text { (dominan) dan } \\
\text { silinder pendek }\end{array}$ & Tidak rapat & Druse & Jaringan bunga karang & - \\
\hline
\end{tabular}


AL-KAUNIYAH: Jurnal Biologi, 14(1), 2021

\begin{tabular}{|c|c|c|c|c|c|c|c|}
\hline \multirow[b]{2}{*}{ Nama spesies } & \multicolumn{3}{|c|}{ Jumlah lapisan dan bentuk } & \multirow{2}{*}{$\begin{array}{l}\text { Kerapatan } \\
\text { jaringan } \\
\text { bunga } \\
\text { karang } \\
\end{array}$} & \multirow{2}{*}{$\begin{array}{c}\text { Bentuk } \\
\text { kalsium } \\
\text { oksalat }\end{array}$} & \multirow{2}{*}{$\begin{array}{c}\text { Keberadaan kalsium } \\
\text { oksalat }\end{array}$} & \multirow[b]{2}{*}{$\begin{array}{c}\text { Kenampakan } \\
\text { khusus }\end{array}$} \\
\hline & Epidermis atas & $\begin{array}{l}\text { Epidermis } \\
\text { bawah }\end{array}$ & Jaringan tiang & & & & \\
\hline $\begin{array}{l}\text { Glochidion } \\
\text { philippicum }\end{array}$ & $\begin{array}{l}2 \text { lapis, sel } \\
\text { seragam }\end{array}$ & $\begin{array}{l}1 \text { lapis, sel } \\
\text { seragam }\end{array}$ & $\begin{array}{l}1 \text { lapis, } \\
\text { memanjang }\end{array}$ & Rapat & Druse & Jaringan bunga karang & - \\
\hline $\begin{array}{l}\text { Glochidion } \\
\text { zeylanicum }\end{array}$ & $\begin{array}{l}1 \text { lapis, sel } \\
\text { seragam }\end{array}$ & $\begin{array}{l}1 \text { lapis, sel } \\
\text { seragam }\end{array}$ & $\begin{array}{l}1 \text { lapis, } \\
\text { memanjang }\end{array}$ & Tidak rapat & Druse, & $\begin{array}{l}\text { Jaringan bunga karang, } \\
\text { jaringan tiang, dan } \\
\text { parenkim berkas } \\
\text { pengangkut }\end{array}$ & - \\
\hline $\begin{array}{l}\text { Phyllanthus } \\
\text { mollis }\end{array}$ & $\begin{array}{l}1 \text { lapis, sel } \\
\text { seragam }\end{array}$ & $\begin{array}{l}1 \text { lapis, sel } \\
\text { seragam }\end{array}$ & $\begin{array}{l}1 \text { lapis, } \\
\text { memanjang }\end{array}$ & Rapat & Druse & Jaringan bunga karang & - \\
\hline
\end{tabular}




\section{PEMBAHASAN}

Stomata memiliki peranan yang penting pada tumbuhan, Merced dan Renzaglia (2017) menyatakan bahwa struktur stomata memiliki peran dalam evolusi tumbuhan, keberadaannya telah ditemukan pada fosil sejak zaman Silurian atas dan mengalami perkembangan mengikuti evolusi tumbuhan. Stomata dapat digunakan sebagai karakter taksonomi yang membedakan antar spesies seperti pada famili Euphorbiaceae (Thakur \& Patil, 2011a). Karakter yang paling sering digunakan adalah tipe stomata. Menurut Metcalfe dan Chalk (1950) stomata pada genus Glochidion ditemukan dengan tipe parasitik sedangkan pada Baccaurea umumnya tipe stomata anisositik, hal ini sesuai dengan hasil pengamatan pada spesies Glochidion dan $B$. nanihua (Gambar 1). Beberapa Glochidion juga memiliki tipe anomositik seperti pada $G$. hohenckeri (Thakur \& Patil, 2014) dan pada penelitian ini tipe anomositik ditemukan pada G. philippicum. Tipe stomata parasitik juga ditemukan pada semua spesies Antidesma, hal ini memungkinkan bahwa karakter stomata untuk sebagian besar anggota genus Antidesma adalah parasitik (Gambar 1) dengan didukung hasil yang sama pada A. acidum (Patil \& Jadhav, 2014) dan A. bunius (Rindyastuti \& Hapsari, 2017). Sedangkan pada Breynia tipe stomata yang ditemukan yaitu anomositik dan parasitik (Gambar 1), hal ini sesuai dengan hasil penelitian Thakur dan Patil (2011a) pada $B$. nivosa. Pengamatan pada $P$. mollis ditemukan tipe stomata parasitik dan anomositik. Tipe stomata pada Phyllanthus cukup beragam seperti contohnya parasitik pada $P$. discoideus dan $P$. reticulatus, anomositik pada $P$. nivosus (Okanume, Ahmad, \& Agaba, 2019) dan anisositik pada $P$. amarus (James, Nethu, \& Antony, 2018).

Karakter stomata dapat digunakan sebagai acuan dalam mempelajari studi asal tanaman, evolusi, dan klasifikasi (Hong, Lin, \& He, 2018). Karakter kuantitatif stomata diantaranya adalah ukuran, kerapatan, dan indeks stomata. Ukuran dan jumlah stomata per satuan area dipengaruhi oleh beberapa hal, seperti lingkungan saat pertumbuhan dan genetik (Casson \& Gray, 2008; DohenyAdams, Hunt, Franks, Beerling, \& Gray, 2012). Hasil pengamatan sampel terhadap ukuran stomata menunjukkan bahwa spesies dalam satu genus menunjukkan ukuran stomata yang tidak terlalu berbeda. Pada Antidesma ukuran panjang stomata berkisar 14,1-16,0 $\mu \mathrm{m}$ dan lebar 11,2-14,7 $\mu \mathrm{m}$. Glochidion memiliki panjang 17,5-20,1 $\mu \mathrm{m}$ dan lebar 10,3-12,8 $\mu \mathrm{m}$ sedangkan pada Breynia panjangnya 14,3-18,7 $\mu \mathrm{m}$ dan lebar 8,5-10,0 $\mu \mathrm{m}$. Pengukuran indeks stomata pada pengamatan hanya dapat menunjukkan nilai indeks tiap spesies dan tidak dapat menggambarkan hubungan indeks stomata dengan genus. Hasil pengamatan yang menunjukkan tidak adanya hubungan indeks stomata dengan genus dimungkinkan karena faktor genetik tiap spesies lebih berperan dalam kasus ini dibandingkan dengan faktor lingkungan, hal ini karena semua sampel diambil pada daerah dengan iklim mikro yang sama. Penelitian oleh Camargo dan Marenco (2011) juga menunjukkan bahwa faktor genetik dapat berperan lebih penting dibandingkan dengan faktor lingkungan yang ditunjukkan dengan distribusi stomata pada 35 tanaman di Hutan Amazon yang tidak terpengaruh oleh perbedaan lingkungan tumbuh.

Trikoma merupakan salah satu karakter anatomi yang dapat digunakan dalam pengelompokan taksa. Jenis trikoma pada Phyllanthaceae cukup beragam bahkan pada tingkat genus. Baccaurea nanihua memiliki trikoma bentuk rambut bintang (stellate tuft), hal ini sesuai dengan Bodegom, Haegens, Van Heuven, dan Baas (2001) yang menyatakan bahwa trikoma yang paling umum ditemukan pada Baccaurea adalah trikoma tunggal uniseluler, namun beberapa spesies diketahui memiliki bentuk trikoma lain contohnya $B$. nanihua dan $B$. costulata dengan bentuk rambut bintang dan $B$. parviflora dengan bentuk sisik bintang (stellate scale). Keberadaan trikoma pada genus Breynia, Glochidion, dan Phyllanthus sangat beragam. Hasil pengamatan menunjukkan bahwa pada Breynia macrantha tidak ditemukan adanya trikoma dan serupa dengan spesies lain yaitu $B$. disticha (Moawed, Saiid, Abdelsamie, \& Tantawy, 2015), sedangkan B. vestita memiliki trikoma tunggal multiseluler yang setipe dengan trikoma pada $B$. nivosa (Thakur et al., 2017). Glochidion sp. dan G. zeylanicum juga tidak memiliki trikoma, spesies lain dari genus 
ini yang juga tidak memiliki trikoma adalah $G$. hohenckeri (Thakur \& Patil, 2014) sedangkan $G$. philippicum memiliki trikoma tunggal uniseluler. Jenis trikoma tunggal uniseluler juga ditemukan pada $G$. velutinum namun dilengkapi juga dengan tipe multiseluler (Sandhya, Rsnakk, Banji, \& Aradhana, 2011). Tipe trikoma pada Phyllanthus mollis adalah tunggal multiseluler. Phyllanthus memiliki variasi yang banyak berhubungan dengan keberadaan dan tipe trikoma pada spesiesnya (Solihani, Noraini, Azahana, \& Nordahlia, 2015; Thakur et al., 2017).

Struktur transversal daun sampel yang diamati memiliki susunan yang cenderung sama. Beberapa karakter anatomi spesifik terlihat pada genus tertentu. Karakteristik pada genus Antidesma pada pengamatan yaitu jumlah jaringan tiang lebih dari satu lapis dengan bentuk dominan silinder pendek dan persegi serta sel penyusun epidermis atas yang tidak seragam (berbeda ukuran). Epidermis atas dengan bentuk yang tidak seragam juga ditemukan pada A. bunius (Rindyastuti \& Hapsari, 2017). Breynia, Glochidion, dan Phyllanthus pada pengamatan ini umumnya memiliki jaringan tiang berbentuk memanjang kecuali B. macrantha yang memiliki bentuk jaringan tiang silinder pendek. Struktur daun pada $B$. nanihua memiliki karakteristik yang berbeda dibanding spesies dari genus lain. Karakter ini dimungkinkan ciri dari genus Baccaurea. Beberapa karakteristik pada $B$. nanihua yang sesuai dengan hasil pengamatan dari Bodegom et al. (2001) terhadap 43 spesies Baccaurea adalah adanya kristal druse pada mesofil daun, beberapa spesies juga memilikinya pada epidermis atas seperti pada B. nanihua, B. nesophila dan B. tetrandra. Selain itu, lapisan jaringan tiang pada Baccaurea umum ditemukan lebih dari selapis (dengan bentuk yang bermacam). Karakteristik tingkat individu ditemukan pada $G$. philippicum dengan terdapatnya hipodermis atas dan $B$. cernua yang memiliki hipodermis pada bagian berkas pengangkut di tulang daun.

Struktur berkas pengangkut baik pada tangkai dan tulang daun juga dapat digunakan sebagai karakter taksonomi. Penelitian terdahulu yang dilakukan oleh Bodegom et al. (2001) pada beberapa genus dari famili Euphorbiaceae (sebelum dipecah menjadi beberapa famili baru), termasuk Baccaurea, mengemukakan bahwa pada umumnya bentuk berkas pengangkut pada tangkai dan tulang daun sama. Pasini dan Mirjalili (2006) mengelompokkan dua bentuk umum berkas pengangkut pada tangkai dan tulang daun, yaitu bentuk lonjong dan semi-lonjong. Pengelompokan ini didasarkan pada penyatuan jaringan xilem dan floem dalam satu lingkaran penuh (lonjong) atau hanya setengah lingkaran (semi-lonjong)

Sampel Phyllanthaceae yang diamati terdiri dari lima genus, yaitu Antidesma, Baccaurea, Breynia, Glochidion, dan Phyllanthus. Pengamatan tangkai dan tulang daun menunjukkan adanya empat bentuk yang cukup menggambarkan pada masing-masing genus (Gambar 3). Berdasarkan pengelompokan dari Pasini dan Mirjalili (2006), genus Antidesma dan Baccaurea memiliki berkas pengangkut bentuk lonjong. Sementara itu pada genus Glochidion, Breynia, dan Phyllanthus memiliki berkas pengangkut bentuk semi lonjong.

Berkas pengangkut bentuk lonjong terdapat pada Antidesma dan Baccaurea. Genus Antidesma memiliki tiga berkas pengangkut, yaitu satu berkas pengangkut berukuran besar dan dua berkas pengangkut berukuran kecil. Hasil penelitian lainnya pada Antidesma acidum (Patil \& Jadhav, 2014) juga menunjukkan berkas pengangkut dengan bentuk yang serupa. Dapat dilihat pada berkas pengangkut besar mengandung parenkim (empulur) dibagian tengah, sedangkan pada berkas pengangkut kecil hanya terdiri dari xilem dan floem. Sedangkan berkas pengangkut pada Baccaurea memiliki jaringan parenkim yang cukup luas dibagian tengah berkas pengangkut. Data mengenai anatomi berkas pengangkut pada Baccaurea masih sangat terbatas.

Menurut Serebrynaya, Nasuhova, dan Konovalov (2017), tipe berkas pengangkut pada Breynia serupa dengan tipe tangkai daun Laurus nobilis (Lauraceae), yaitu tipe semilunar yang ditunjukkan dengan posisi floem yang menumpang dibawah xilem sehingga membentuk pertemuan sel pada kedua ujung berkas pengangkut yang hampir sejajar. Tipe semi lunar pada pengamatan ditemukan pada tangkai dan tulang daun dari $B$. cernua dan $B$. 
vestita, tipe ini juga ditemukan pada $B$. nivosa (Thakur \& Patil, 2011b). Pengamatan tangkai dan tulang daun pada $B$. macrantha menunjukkan adanya perbedaan tipe berkas pengangkut pada tulang daun dan tangkai daun. Tipe berkas pengangkut pada tulang daun menyerupai $B$. cernua dan $B$. vestita, yaitu tipe semi lunar sedangkan pada tangkai daun menyerupai Glochidion, yaitu bentuk menyerupai ginjal. Tipe berkas pengangkut tangkai daun dengan bentuk menyerupai ginjal pada genus Breynia juga ditemukan pada $B$. disticha (Moawed et al., 2015). Hal ini mengindikasikan bahwa berkas pengangkut pada genus Breynia memiliki rentang dari semi lunar sampai menyerupai ginjal.

Tipe berkas pengangkut pada Glochidion cukup bervariasi. Pada pengamatan ditemukan tiga tipe berbeda dengan tambahan berkas pengangkut, namun jika diperhatikan lebih jauh bentuk dasar dari berkas pengangkutnya adalah tipe menyerupai ginjal. Tipe menyerupai ginjal yang sederhana (tanpa ada tambahan berkas pengangkut) ditemukan pada G. hohenckeri (Thakur \& Patil, 2011b).

Genus Phyllanthus yang diwakili oleh $P$. mollis pada pengamatan ini memiliki berkas pengangkut tangkai dan tulang daun tipe semi lunar yang menyerupai $B$. cernua dan $B$. vestita. Berkas pengangkut pada tangkai daun $P$. mollis memiliki tipe yang sama dengan $P$. debilis dan sedikit berbeda dengan $P$. airyshawii pada bagian adaksialnya yang lebih cembung dibandingkan $P$. mollis meskipun susunan xilem dan floemnya sama (Tadavi \& Bhadane, 2014). Tipe berkas pengangkut tulang daun $P$. mollis juga memiliki susunan yang sama dengan beberapa Phyllanthus asal Nigeria seperti $P$. muellerianus (Awomukwu, Nyananyo, Uka, \& Okeke, 2015).

Struktur berkas pengangkut pada tulang daun maupun tangkai daun pada genus Glochidion, Breynia dan Phyllanthus memiliki bentuk dan susunan yang hampir sama. Hal ini dimungkinkan karena berdasarkan studi filogenetik molekular, genus Glochidion, Breynia, dan Sauropus memiliki kekerabatan yang dekat dengan Phyllanthus. Bahkan beberapa peneliti menyarankan genus tersebut dilebur dan menjadi super genus Phyllanthus s.l. (Hoffmann, Kathriarachchi, \& Wurdack, 2006; Kathriarachchi et al., 2006). Berdasarkan studi morfologi pada spesies Phyllanthaceae juga terlihat bahwa ke-4 genus tersebut memiliki kekerabatan yang dekat (terutama Breynia dan Sauropus) (Van Welzen, Pruesapan, Telford, Esser, \& Bruhl, 2014; Vanlalhruaia \& Lalbiaknunga, 2020). Namun, peleburan genus Glochidion, Breynia, dan Sauropus ke dalam Phyllanthus s.l dianggap tidak tepat karena masih bisa dibedakan secara morfologi pada beberapa karakter, contohnya pada morfologi bunga dan percabangan phyllanthoid (Vanlalhruaia \& Lalbiaknunga, 2020).

\section{SIMPULAN DAN SARAN}

Keseluruhan data yang didapat menggambarkan terdapatnya karakteristik pada tingkat genus maupun spesies. Karakter pada genus Antidesma dalam pengamatan adalah memiliki epidermis atas dengan ukuran sel yang tidak seragam, dinding antiklinal epidermis bergelombang sampai melekuk, jumlah jaringan tiang lebih dari satu lapis dengan bentuk silinder pendek, stomata parasitik dan berkas pengangkut terdiri dari tiga berkas. Genus Glochidion secara umum memiliki kesamaan dalam bentuk jaringan tiang memanjang dan bentuk berkas pengangkut tangkai daun dengan bentuk dasar menyerupai ginjal, karakter spesifik ditemui pada $G$. philippicum dengan terdapatnya hipodermis atas. Anggota genus Breynia memiliki dua tipe stomata (parasitik dan anomositik) serta bentuk berkas pengangkut tangkai dan tulang daun tipe semi lunar sampai menyerupai ginjal. Phyllanthus memiliki bentuk berkas pengangkut tangkai daun tipe semi lunar, sedangkan $B$. nanihua memperkuat data spesies-spesies genus Baccaurea yang memiliki kristal druse pada epidermisnya serta bertrikoma bentuk rambut bintang, sedangkan karakter individu $B$. nanihua adalah bentuk jaringan tiang yang meruncing.

Struktur anatomi daun dan tangkai daun dapat digunakan sebagai karakter spesifik taksonomi. Beberapa karakter memiliki kekhususan pada tingkat genus dan beberapa khas pada tingkat spesies. Karakter anatomi juga dapat menggambarkan hubungan kekerabatan seperti genus Glochidion, Breynia dan Phyllanthus yang memiliki struktur berkas 
pengangkut daun dan tangkai daun yang hampir sama.

\section{UCAPAN TERIMA KASIH}

Penulis mengucapkan terima kasih kepada tim eksplorasi Banggai Kepulauan, Pusat Penelitian Biologi LIPI atas sampel Phyllanthaceae yang didapat.

\section{REFERENSI}

Awomukwu, D., Nyananyo, B., Uka, C., \& Okeke, C. U. (2015). Identification of the genus Phyllanthus (Family Phyllathaceae) in Southern Nigeria using comparative systematic morphological and anatomical studies of the vegetative organs. Journal of Plant Sciences, 3(3), 137-149.

doi: 10.11648/j.jps.20150303.15

Aziagba, A., Okwuchukwu, B., Ke, O., \& Uwabukeonye, C. (2017). Taxonomic significance of stem and petiole anatomy of three white varieties of Vigna unguiculata. American Journal of Life Science Researches, 5(1), 1-5. doi: 10.21859/ajlsr-05011.

Bodegom, S., Haegens, R. M. A. P., Van Heuven, B. J., \& Baas, P. (2001). Systematic leaf anatomy of Baccaurea, Distichirhops, and Nothobaccaurea (Euphorbiaceae). Blumea: Journal of Plant Taxonomy and Plant Geography, 46(3), 485-497.

Cahyanto, T., Sopian, A., Efendi, M., \& Kinasih, I. (2017). Grouping of Mangifera indica L. cultivars of Subang West Java by leaves morphology and anatomy characteristics. Biosaintifika: Journal of Biology \& Biology Education, 9(1), $156 . \quad$ doi: 10.15294/biosaintifika.v9i1.8780.

Camargo, M. A. B., \& Marenco, R. A. (2011). Density, size and distribution of stomata in 35 rainforest tree species in Central Amazonia. Acta Amazonica, 41(2), 205212 . doi: 10.1590/S004459672011000200004.

Casson, S., \& Gray, J. E. (2008). Tansley review: Influence of enviromental factors on stomatal development. New Phytologist 178, 9-23. doi: 10.1111/j.1469-8137.2007.02351.x.
Cutler, D. F. (1978). Applied plant anatomy. Longman. London and New York.

Doheny-Adams, T., Hunt, L., Franks, P. J., Beerling, D. J., \& Gray, J. E. (2012). Genetic manipulation of stomatal density influences stomatal size, plant growth and tolerance to restricted water supply across a growth carbon dioxide gradient. Philosophical Transactions of The Royal Society B, 367(1588), 547-555. doi:10.1098/rstb.2011.0272.

Hoffmann, P., Kathriarachchi, H., \& Wurdack, K. J. (2006). A Phylogenetic classification of Phyllanthaceae (Malpighiales; Euphorbiaceae sensu lato). Kew Buletin, 61, 37-53. doi : 124.158.189.56.

Hong, T., Lin, H., \& He, D. (2018). Characteristics and correlations of leaf stomata in different Aleurites montana Provenances. PLoS ONE, 13(12), 1-10. doi: 10.1371/journal.pone.0208899.

James, J. M., Nethu, P. C., \& Antony, T. (2018). A comparative study of morphoanatomical, fluorescent characteristics, phytochemical and antibacterial studies of two different Phyllanthus species of Kerala. Journal of Pharmacognosy and Phytochemistry, 7(4), 3225-3234.

Kathriarachchi, H., Samuel, R., Hoffmann, P., Mlinarec, J., Wurdack, K.J., Ralimanana, H., ... Chase, M. W. (2006). Phylogenetics of tribe Phyllantheae (Phyllanthaceae; Euphorbiaceae sensu lato) based on nrITS and plastid matK DNA sequence data. American Journal of Botany, 93(4), 637-655. doi : 10.3732/ajb.93.4.637.

Metcalfe, C. R., \& Chalk, L. (1950). Anatomy of the Dicotyledons vol. 1. Oxford: Clarendon Press.

Merced, A., \& Renzaglia, K. S. (2017). Structure, function and evolution of stomata from a bryological perspective. Bryophyte Diversity \& Evolution, 39(1), 7-20. doi: 10.11646/bde.39.1.4.

Moawed, M. M., Saiid, S., Abdelsamie, Z., \& Tantawy, M. (2015). Phenetic analysis of certain taxa of Euphorbiaceae grown in Egypt. Egypt Journal Botany 55(2), 247267. doi: 10.21608/EJBO.2015.216.

Okanume, O. E., Ahmad, M. Z., \& Agaba, O. 
A. (2019). Morphological and leaf epidermal features of some Phyllanthus species in Jos, Nigeria. Annals of West Universityof Timisoara, Series of Biology, 22(1), 47-56.

Pasini, D., \& Mirjalili, V. (2006). The optimized shape of a leaf petiole. WIT Transactions on Ecology and The Environment, 87, 35-45. doi: 10.2495/DN060041.

Patil, P., \& Jadhav, V. (2014). Short communication pharmacognostical evaluation of Antidesma acidum Retz. leaf: A wild edible plant. Journal of Advanced Scientific Research, 5(1), 2831.

Rindyastuti, R., \& Hapsari, L. (2017). Adaptasi ekofisiologi terhadap iklim tropis kering: Studi anatomi daun sepuluh jenis tumbuhan berkayu. Indonesian Journal of Biology, 13(1), 1-14. doi: 10.14203/jbi.v13i1.3089.

Sandhya, S., Rsnakk, C., Banji, D., \& Aradhana. (2011). Microscopical and physiochemical studies of Glochidion velutinum leaf. Journal of Global Trends in Pharmaceutical Sciences, 2(1), 91107.

Sass, J. E. (1951). Botanical microtechnique 2nd edition. Iowa: The IOWA State College Press.

Serebrynaya, F. K., Nasuhova, N. M., \& Konovalov, D. A. (2017). Morphological and anatomical study of the leaves of Laurus nobilis L. (Lauraceae), growing in the introduction of the Northern Caucasus Region (Russia). Pharmacognosy Journal, 9(4), 519-522. doi: $10.5530 / \mathrm{pj} .2017 .4 .83$.

Solihani, N. S., Noraini, T., Azahana, A., \& Nordahlia, A. S. (2015). Leaf micromorphology of some Phyllanthus L. species (Phyllanthaceae). AIP Conference Proceedings 1678, 020022(2015). doi: 10.1063/1.4931207.

Tadavi, S. C., \& Bhadane, V. V. (2014). Taxonomic of the rachis, petiole and petiolule anatomy in some Euphorbiaceae. Biolofe, 2(3), 850-857.
Thakur, H. A., \& Patil, D. A. (2011a). The foliar epidermal studies in some hitherto unstudied Euphorbiaceae. Current Botany, 2(4), 22-30.

Thakur, H. A., \& Patil, D. A. (2011b). Petiolar anatomy of some unstudied Euphorbiaceae. Journal of Phytology, 2(12), 54-59.

Thakur, H. A., \& Patil, D. A. (2014). Foliar epidermal studies of plants in Euphorbiaceae. Taiwania, 59(1), 59-70. doi: 10.6165/tai.2014.59.59.

Thakur, U., Prajapati, A., Guhe, G., Inamdar, S., Sontakke, P., Ikhare, S., \& Bhise, P. (2017). Foliar epidermal studies of some species of family Euphorbiaceae. Hislopia Journal, 10(1), 43-51.

Van Cotthem, W. R. J. (1970). A classification of stomatal types. Botanical Journal of the Linnean Society, 63(3), 235-246. doi: 10.1111/j.1095-8339.1970.tb02321.x.

Van Welzen, P. C., Pruesapan, K., Telford, I. R. H., Esser, H. -J. \& Bruhl, J. J. (2014). Phylogenetic reconstruction prompts taxonomic changes in Sauropus and Breynua (Phyllanthaceae tribe Phyllantheae). Blumea, 59, 77-94. doi: 10.3767/000651914X684484.

Vanlalhruaia., \& Lalbiaknunga, J. (2020). A study of phylogeny of Phyllanthaceae using morphological features. International Journal of Botany Studies, 5(6), 1-4.

Whitmore, T. C. (1991). Perspectives in tropical rain forest research. In A. E. Lugo, \& C. Lowe (Eds.), Tropical forests: Management and ecology (pp. 397-407). New York, US: Springer Verlag New York Inc.

Wilmer, C. M. (1983). Stomata. London: Longman Group Ltd.

Wu, J., \& Vankat, J. L. (1995). Island biogeography: Theory and applications. In W. A. Nierenberg (Eds.), Encyclopedia of environmental biology vol. 2 (pp. 371-379). San Diego, US: Academic Press. 